\title{
RANCANGAN STRATEGI SAMUDERA BIRU PT. SILKARGO INDONESIA SAMUDERA INDONESIA GROUP (2010 - 2014)
}

\author{
Ina Astari Utaminingsih \\ Program Studi S2 Magister Manajemen Eksekutif Muda \\ Sekolah Tinggi Manajemen PPM
}

\begin{abstract}
Dengan meningkatnya dinamika persaingan di industri logistic, SILkargo memandang perlu adanya terobosan strategis agar dapat terus menjadi pemain yang diperhitungkan di industry. Hal ini sesuai dengan strategi korporat Samudera Indonesia Group. Oleh sebab itu diputuskan untuk menggunakan pendekatan samudera biru untuk mengembangkan suatu alternatif stretegi yang dipandang inovatif. Hasil studi memberikan kanvas strategi dengan kurva nilai baru, eliminasi asset ownership, penurunan harga dan nama global, meningkatkan jejaring, penggunaan teknologi informasi, emnciptakan vendor management dan meningkatkan safety. Hasil studi juga meghasilkan rekomendasi untuk meningkatkan kegiatan otomasi, sistem pengendalian dan vendor management.
\end{abstract}

Keywords:

Industri logistik, strategi samudera biru, inovasi 


\section{PENDAHULUAN}

Industri logistik di Indonesia berkembang sangat pesat. Meski krisis global terjadi mulai tahun 2008 membuat banyak kalangan pelaku industri menghentikan produksinya, yang selanjutnya berdampak pada penurunan permintaan kebutuhan logistik termasuk delivery, tetapi industri logistik nasional masih tetap tumbuh. Penawaran dan permintaan di pasar ritel Indonesia masih meningkat perlahan, bahkan industri logistik itu sendiri mampu tumbuh 3\% - angka yang cukup baik di tengah masa sulit seperti sekarang.

PT. SILkargo Indonesia (selanjutnya akan disebut SILkargo) merupakan anak perusahaan Samudera Indonesia Group, yang bergerak di bidang logistics service provider. Dalam hal produk dan jasa yang ditawarkan oleh SILkargo kepada para pelanggannya merupakan sesuatu yang kurang lebih sama dengan yang ditawarkan oleh para kompetitor sejak bisnis awal sebelum dibentuk menjadi logistik terintegrasi (freight forwarder). Dalam hal target pelanggan SILkargo juga menjadi tidak fokus dan terlalu meluas, mengingat banyaknya macam pergerakan kargo yang masuk ke dalam jenis sasaran jasa industri ini.

Dengan kondisi kompetisi industri logistik yang semakin ketat dan bertambah jumlah pemainnya, kemudian memunculkan adanya suatu kebutuhan akan rancangan strategik yang baru dan bersifat inovatif, beserta dengan rangkaian kegiatan di dalamnya. Kim dan Mauborgne (2009) sudah sejak lama melihat adanya fenomena seperti itu. Dari situ mereka berfikir untuk menciptakan kondisi pasar yang baru, yaitu yang bersifat Blue Ocean. Strategi yang akan diaplikasikan dalam kondisi pasar tersebut dinamakan Blue Ocean Strategy. Tidak dapat dihindari bahwa strategi ini merupakan salah satu teknik yang sebaiknya mulai dilakukan ketika sebuah perusahaan hendak memenangkan kompetisi bisnis yang semakin ketat.

Berdasarkan situs resmi Blue Ocean Strategy (http://www. blueoceanstrategy. com) bahwa terdapat sepuluh hal yang bisa dicek untuk mengetahui apakah sebenarnya suatu perusahaan berada dalam ruang samudera merah atau justru sudah dalam samudera biru. Sepuluh poin ini dinamakan Check-list : How blue is your ocean? yang dapat di diskusikan dengan pihak internal perusahaan tersebut. Dari kesepuluh poin ini apabila sebagian besar terjadi di perusahaan maka dapat dikatakan bahwa perusahaan tersebut berada pada samudera merah. Hal inilah yang terjadi ketika dicek pada kondisi SILkargo yang memang sebagian besar menunjukkan adanya fenomena tersebut.

Disinilah perlu adanya rancangan Blue Ocean Strategy yang dapat menawarkan SILkargo agar keluar dari ruang samudera merah. Dari rancangan ini akan disajikan konsep, alat, dan kerangka kerja yang menjadikan SILkargo keluar dari kompetisi dan menciptakan nilai baru bagi pelanggan. Hal ini dapat menciptakan bisnis yang bersifat unggul dan berkelanjutan. Dengan begitu permasalahan yang menjadi topik penelitian adalah bagaimana rancangan strategi baru SILkargo (periode 2010 - 2014) dalam mengatasi kondisi persaingan bisnis yang semakin ketat. Rumusan dalam bentuk faktor kompetisi dan kegiatan (langkah kerja) seperti apa yang harus dihasilkan agar strategi tersebut bersifat kreatif, inovasi dan menawarkan nilai lebih kepada pelanggan.

Tujuan penelitian ini adalah untuk merumuskan beberapa hal, yaitu : Six Path Framework Blue Ocean Strategy pada SILkargo dengan cara identifikasi enam asumsi pokok yang mendasari strategi 
perusahaan mengenai persaingan, Strategy Canvas, Four Actions Framework dan ERRC grid berdasarkan identifikasi yang didapat dari hasil sebelumnya Dari inilah kemudian dihasilkan suatu rangkaian kegiatan baru dan bersifat inovatif bagi SILkargo, yang juga layak secara komersil melalui Sequence of Blue Ocean Strategy. Sedangkan kontribusi yang diharapkan dari penelitian ini yaitu : (1) Hasil analisa dapat digunakan sebagai referensi ketika melakukan studi atau penelitian yang bersifat perencanaan strategik, (2) Dengan mengetahui adanya alternatif strategi yang baru dan inovatif dalam industri logistik ini, dapat menciptakan perusahaan yang terus tumbuh dan berkinerja tinggi dan juga memberikan efek kuat menanamkan merek perusahaan dalam benak pembeli.

Penelitian ini dibatasi dalam ruang lingkup yaitu : (1) Perusahaan adalah SILkargo (cabang Jakarta) beserta cakupan industrinya dengan menggunakan data periode tahun 2007 - 2009, (2) Jenis cakupan jasa dibatasi pada proses Outbond Domestic atau Inter-insular dengan titik awal di Jakarta, (3) Strategi Blue Ocean yang dirancang menggunakan empat alat analisa. Dalam merekonstruksi batasan pasar menggunakan six path framework, sedangkan merumuskan rangkaian kegiatan strategisnya melalui strategy canvas, four actions framework, ERRC grid, dan four actions strategic sequences.

\section{TINJAUAN PUSTAKA}

Menurut Kim dan Mauborgne (2005) sebagai pelopor Strategi samudra biru atau dikenal dengan Blue Ocean Strategy (selanjutnya akan disebut BOS) menyatakan bahwa BOS merupakan sebuah terobososan strategi perusahaan untuk keluar dari samudra merah (Red Ocean). Dasar membuat samudera biru adalah inovasi nilai dan hanya terjadi ketika perusahaan memadukan inovasi dengan manfaat, harga, dan posisi biaya. Inovasi nilai menolak salah satu dogma yang paling umum digunakan dalam strategi berbasiskan kompetisi yaitu : dilemma atau pertukaran nilai - biaya. BOS menjadikan perusahaan mengejar diferensiasi dengan biaya rendah secara bersamaan.

Kim dan Mauborgne (2005) telah mengembangkan perangkat kerja untuk menganalisis BOS agar perumusannya menjadi sistematis dan praktis yaitu sebagai berikut :

\section{Six Path Framework}

Six Path Framework (selanjutnya akan disebut Enam Kerangka Kerja) merupakan proses identifikasi tahapan yang ditempuh secara sistematis untuk menciptakan ruang pasar dimana belum ada pesaingnya. Kerangka kerja ini dilakukan dengan cara mencermati enam asumsi pokok yang mendasari strategi di banyak perusahaan mengenai persaingan, yaitu : industri alternatif, kelompok strategis dalam industri, rantai pembeli, penawaran produk dan jasa pelengkap, daya tarik emosional atau fungsional bagi pembeli, waktu.

\section{Strategy Canvas}

Strategy Canvas (selanjutnya akan disebut Kanvas Strategi) ini merupakan kerangka aksi sekaligus diagnosis untuk membangun BOS yang baik. Kanvas Strategi memiliki dua fungsi yaitu : merangkum situasi terkini dalam ruang pasar yang sudah dikenal dan merangkum tingkat penawaran yang didapatkan pembeli di semua faktor utama kompetisi.

3. Four Actions Framework

Four Actions Framework (selanjutnya akan disebut Kerangka kerja empat langkah) dikembangkan untuk merekonstruksi elemen nilai pembeli dalam membuat kurva nilai baru. Kerangka kerja empat langkah ini terdiri dari empat pertanyaan kunci untuk 
menantang logika strategi dan model bisnis yaitu sebagai berikut : faktor apa saja yang harus "dihapuskan", faktor apa saja yang harus "dikurangi", faktor apa saja yang harus "ditingkatkan”, faktor apa saja yang harus "diciptakan".

\section{ERRC Grid}

Alat analisis ini merupakan pelengkap bagi kerangka kerja empat langkah. ERRC Grid (selanjutnya akan disebut Skema ERRC) ini biasa diartikan sebagai kegiatan yang terdiri dari : Hapuskan - Kurangi Tingkatkan - Ciptakan. Skema ini mendorong perusahaan untuk tidak hanya menanyakan empat pertanyaan, tetapi juga bertindak berdasarkan keempat pertanyaan itu untuk menciptakan suatu kurva nilai baru.

5. Sequence of BOS

Sequence of BOS (selanjutnya akan disebut rangkaian kegiatan BOS) ini dapat memastikan suatu model bisnis kuat yang akan dibangun berdasarkan strategi BOS itu adalah benar dan layak secara komersil. Dilakukan identifikasi rangkaian strategis melalui beberapa pengujian sebagai berikut : utilitas istimewa bagi pembeli, pemberian harga strategis, pembiayaan yang ditargetkan (sasaran), pengadopsian.

\section{METODOLOGI}

\subsection{Jenis Penelitian}

Hasil peneliitian yang dilakukan ini berupa rancangan strategis perusahaan dan termasuk kedalam jenis penelitian terapan yang bersifat dekriptif yaitu memberikan suatu penjelasan detail tanpa disertai dengan adanya uji-hipotesis. Keputusan manajerial dan tindakan yang telah dihasilkan dalam tesis ini berada dalam cakupan unit bisnis strategik yang bersifat BOS. Dengan begitu pendekatan yang digunakan untuk menggali data dan informasi di lapangan adalah pendekatan kualitatif.

\subsection{Metode Pengumpulan Data}

Data yang digunakan dalam analisis penelitian ini yaitu : (1) Data primer : hasil wawancara terhadap pihak kunci atau para ahli di dalam SILkargo itu sendiri (internal), pihak kunci atau ahli di luar SILkargo (eksternal), beserta pihak dari ALI (Asosiasi Logistik Indonesia). Data yang diperoleh nantinya diharapkan untuk identifikasi faktor kompetisi sebagai dasar pembuatan kanvas strategi, (2) Data sekunder : data internal atau dokumentasi perusahaan, situs resmi SILkargo Indonesia, Samudera Indonesia Group, dan BOS. Selain itu data pendukung lainnya yaitu artikel, laporan penelitian, buku, dan sumber lainnya dari internet yang berkaitan dengan topik penelitian.

\subsection{Metode Analisis dan Penyajian Data}

Analisis data yang dilakukan dalam penelitian ini dengan cara merekonstruksi batasan pasar yang telah ada (industri logistik). Setelah mendapatkan data dan informasi mengenai detail gambaran industri dan perusahaan, maka akan dicermati industri alternatif, kelompok strategis, kelompok pembeli, tawaran produk dan jasa pelengkap, orientasi fungsional dan emosional industri, dan tren waktu. Kemudian selanjutnya dapat dirumuskan rencana kegiatan baru dan yang bersifat BOS di SILkargo.

Hasil dari analisis diinterpretasikan untuk memperoleh fakta yang terjadi dan kesimpulan yang menjawab tujuan dari penelitian ini. Selain itu analisis kualitatif melalui data wawancara untuk mendapatkan data lebih mendalam dan akurat juga akan disajikan pada laporan penelitian ini. 


\section{KERANGKA ANALISIS}

Kerangka analisis penelitian (Gambar 1.) ini diawali dengan dilakukannya proses rekonstruksi batasan pasar yang ada dan identifikasi beberapa alternatif di dalamnya melalui enam kerangka kerja. Setelah mendapatkan hasil analisis tersebut lalu kemudian dilanjutkan dengan proses identifikasi langkah kegiatan BOS secara praktis sehingga menghasilkan suatu rangkaian kegiatan BOS yang benar dan layak secara komersil.
Perlu diketahui bahwa pada penelitian ini juga mengemukakan adanya hasil analisis internal perusahaan dan eksternal. Analisis ini dilakukan berdasarkan kondisi yang terjadi pada umumnya saat ini (bersifat konvensional) dan menjadi dasar untuk mengidentifikasi alternatif faktor lainnya pada bagian enam kerangka kerja. Adapun data yang digunakan sebagai analisis internal dan eksternal tersebut menjadi sebuah input dalam penelitian ini.

\section{Six Path - Framework}

\begin{tabular}{|c|}
\hline Path One \\
Alternative Industry Identification \\
Path Two \\
Alternative Strategic Group Identification \\
Path Three \\
Alternative Buyer Group Identification \\
Path Four \\
Alternative Product \& Service Offering Identification \\
Path Five \\
Alternative Orientation of an Industry Identification \\
\hline Path Six \\
Industry Trend Identification \\
\hline
\end{tabular}

Blue Ocean Strategy Actions

\begin{tabular}{|c|c|c|}
\hline Canvas Strategy & Four Actions Framework & ERRC Grid \\
\hline \multicolumn{3}{|c|}{ Sequence of Blue Ocean Strategy } \\
\hline
\end{tabular}

Gambar 1.

Kerangka Analisis Penelitian

Kerangka yang digunakan ketika melakukan analisis data penelitian ini dijelaskan secara lebih detail melalui pokok pembahasan sebagai berikut :
4.1 Enam Kerangka Kerja

4.1.1 Path One - Alternative Industry Identification

Pada bagian ini akan dilakukan analisis awal enam kerangka kerja yaitu identifikasi industri alternatif. Alternatif disini maksudnya lebih luas dari substitusi. 
Alternatif mencangkup produk atau jasa yang memiliki fungsi dan bentuk berbeda, tetapi bisa dengan tujuan yang sama. Dengan mencermati alternatif dari industri logistik dan fokus kepada faktor utama yang menuntun pelanggan untuk bertukar melintasi industri alternatif dan menghilangkan serta mengurangi elemen lainnya, maka akan muncul inovasi nilai lalu menciptakan Blue Ocean of new market space.

\subsubsection{Path Two - Alternative Strategic Group Identification}

Pada bagian ini akan dilakukan identifikasi terhadap kelompok strategis dalam industri. Kelompok industri pada tesis ini merujuk pada sekelompok perusahaan dalam industri logistik yang mengejar strategi yang sama. Tahap ini harus dapat mendobrak wawasan sempit dengan cara memahami faktor apa saja yang menentukan keputusan pelanggan ketika berpindah ke kelompok strategis lainnya.

\subsubsection{Path Three - Alternative Buyer Group Identification}

Pada bagian ini akan dilakukan identifikasi terhadap rantai pembeli jasa SILkargo (apakah purchaser, user, atau influencer). Disini akan terlihat pembeli mana yang biasanya menjadi fokus industri ini. Selain itu juga akan dicari bagaimana memunculkan inovasi nilai jika diubah kelompok pembeli dalam industri ini.

\subsubsection{Path Four - Alternative Product and Service Offering Identification}

Pada bagian ini akan dilakukan identifikasi terhadap penawaran produk dan jasa pelengkap dalam industri logistik ini. Dengan mencermati konteks tempat produk dan jasa SILkargo maka dapat diketahui apa yang terjadi sebelum, selama, dan sesudah produk dan jasa tersebut digunakan. Selain itu juga dilakukan identifikasi poin masalah yang ada lalu bagaimana cara untuk menghilangkannya melalui penawaran produk dan jasa pelengkap tersebut.

\subsubsection{Path Five- Alternative Orientation of an Industry Identification}

Pada bagian ini akan dilakukan identifikasi terhadap orientasi daya tarik fungsional dan emosional industri. Industri yang berkompetisi terutama pada harga dan berfungsi berdasarkan kalkulasi utilitas maka daya tariknya bersifat fungsional (rasional). Sedangkan ketika industri berkompetisi terutama pada perasaan dan dapat berkaitan dengan menumbuhkan emosi pelanggannya maka daya tariknya bersifat emosional. Disini akan dicermati industri berkompetisi pada daya tarik yang mana. Jika fungsional, maka elemen apa saja yang bisa ditambahkan agar menjadikannya emosional. Sebaliknya jika emosional, maka elemen apa saja yang bisa dihilangkan untuk menjadikannya fungsional.

\subsubsection{Path Six - Industry Trend Identification \\ Pada bagian ini akan dilakukan} identifikasi terhadap proses berjalannya waktu, dari nilai yang diberikan oleh pasar saat ini ke nilai yang mungkin diberikan pasar di masa depan. Disini akan dilihat tren bagaimana yang memiliki kemungkinan sangat mempengaruhi industri ini, yang tidak bisa diputarbalik, dan berkembang dalam lintasan waktu yang jelas. Dari identifikasi inilah diharapkan dapat membuka utilitas yang belum pernah ada sebelumnya bagi konsumen.

\subsection{Langkah Kegiatan BOS}

Pada langkah ini mulai merumuskan suatu rangkaian kegiatan baru dan praktis bagi SILkargo. Rangkaian kegiatan tersebut haruslah bersifat inovatif dan dirumuskan berdasarkan identifikasi BOS yang didapat 
dari analisis sebelumnya. Langkah disini menggunakan perangkat analisis kanvas strategi, kerangka kerja empat langkah, dan skema ERRC. Selain itu pada akhirnya akan dilakukan pengecekan terhadap rangkaian kegiatan BOS yang mengikuti utilitas bagi pembeli, harga, biaya, dan juga pengadopsian. Langkah ini dapat memperkecil munculnya resiko model bisnis.

\section{HASIL DAN ANALISIS}

\subsection{Lingkungan Internal SILkargo}

SILkargo merupakan salah satu anak perusahaan Samudera Indonesia Group. SILkargo dikembangkan dari unit bisnis yang sudah ada sebelumnya, salah satunya adalah PT. Satuan Harapan, yang bergerak di dalam bidang usaha Freight Forwarding. Satuan Harapan telah di non-aktifkan sebagai induk perusahaan dan pada tanggal 1 Juni 2006 mulai beroperasi secara aktif SILkargo. Selain melakukan perubahan nama dan struktur organisasi, SILkargo juga dituntut untuk memiliki cara pandang yang berbeda terhadap proses bisnis yang ada dan fungsinya sebagai Logistics Service Provider.

Dalam menggambarkan analisa lingkungan internal SILkargo, maka digunakan data BDI tahun 2009 (Gambar 2.). Terlihat bahwa terdapat sepuluh key attribute yang dijadikan penilaian terhadap dua jenis produk dan jasa SILkargo yaitu yang utama adalah berperan sebagai penyedia jasa Logistik, lalu yang produk atau jasa tambahan adalah sebagai penyedia jasa Forwarding. Jika dilihat secara keseluruhan, maka sebenarnya kesepuluh atribut tersebut kurang lebih sama. Hanya saja urutan prioritasnya yang sedikit berbeda. Dengan begitu dapat dikemukakan bahwa perannya sebagai perusahaan penyedia jasa logistik yang ditawarkan SILkargo tidak jauh berbeda dengan perannya sebagai forwarding. Hal ini semakin memperkuat akan perlunya suatu inovasi di dalam strategi perusahaan logistik seperti SILkargo ini untuk masa yang akan datang.

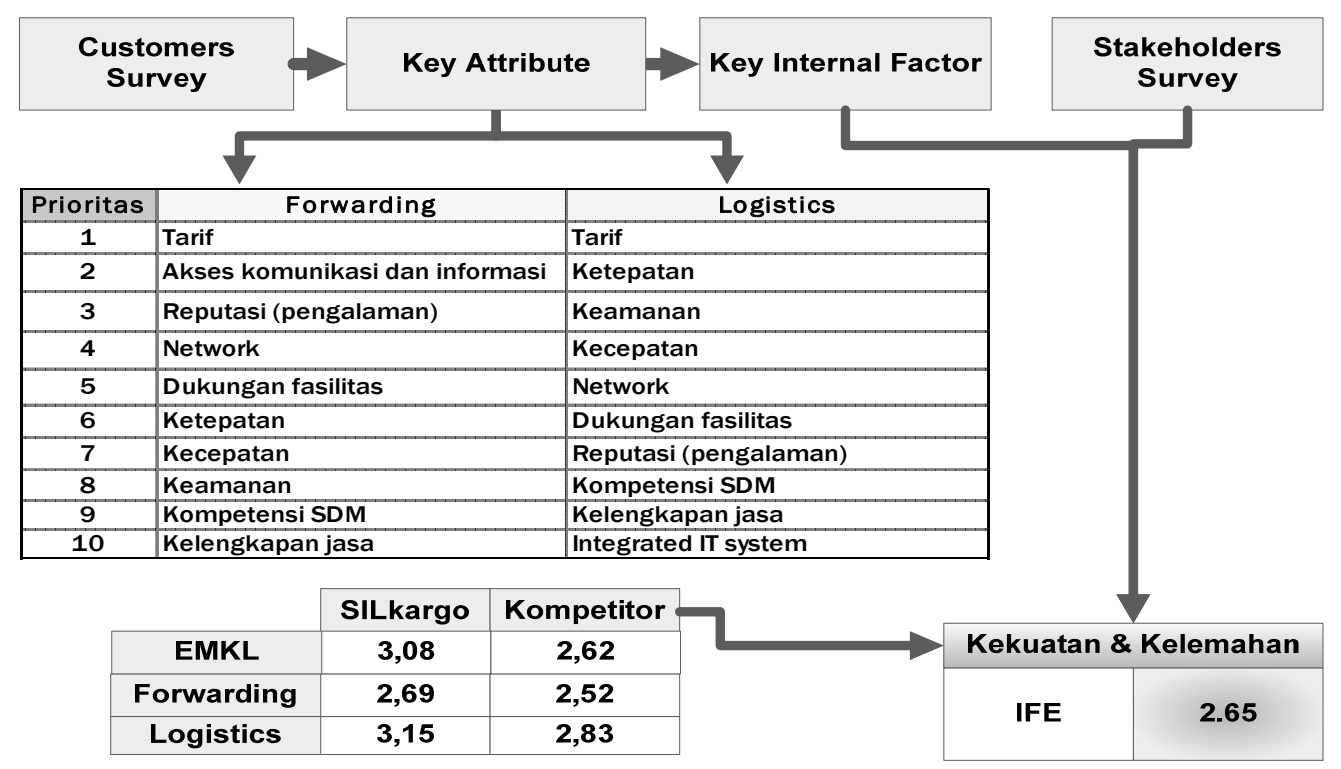

Gambar 2.

Lingkungan Internal SILkargo 
Sedangkan jika melihat bahwa total skor IFE 2,65 yang termasuk berada di atas average score (David 2009). Hal ini menunjukkan bahwa SILkargo berada dalam posisi yang cukup kuat dalam industri yang sejenis, yaitu dalam hal ini industri Logistik. Tetapi perlu diingat bahwa skor 2,65 ini hanya sedikit berada diatas rata - rata $(2,5)$ industri logistik. SILkargo harus semakin meningkatkan keunggulan dan mengatasi kelemahannya lainnya agar menjadi perusahaan yang terus tumbuh dan berkinerja tinggi.

Detail hasil key attribute survey untuk produk dan jasa logistik berdasarkan preferensi pelanggan dapat dilihat pada Tabel 1.

Tabel 1.

Perbandingan Key Attributes Logistik

\begin{tabular}{|c|c|c|c|c|}
\hline \multicolumn{2}{|c|}{ Logistik } \\
\hline Priority & Key Attributes & SILkargo score & Competitor score & Gap \\
\hline 1 & Tarif & 2,83 & 2,95 & $-0,12$ \\
\hline 2 & Kecepatan & 3,06 & 2,64 & 0,42 \\
\hline 3 & Ketepatan & 2,98 & 2,77 & 0,22 \\
\hline 4 & Keamanan & 3,24 & 3,00 & 0,24 \\
\hline 5 & Akses & 3,30 & 2,72 & 0,58 \\
\hline 6 & Dukungan & 3,12 & 2,95 & 0,16 \\
\hline 7 & Network & 3,17 & 2,94 & 0,23 \\
\hline 8 & Kelengkapan & 3,13 & 2,78 & 0,35 \\
\hline 9 & Reputasi & 3,38 & 2,73 & 0,65 \\
\hline 10 & Kompetensi SDM & 3,30 & 2,83 & 0,47 \\
\hline & Average & 3,15 & 2,83 & 0,32 \\
\hline
\end{tabular}

Dari tabel tersebut dapat dikatakan bahwa SILkargo menggunakan prinsip yang paling umum dalam strategi basis kompetisi, yaitu prinsip pertukaran. Dikenakannya tarif yang lebih mahal dibanding kompetitornya (skor rendah), SILkargo menawarkan keunggulan lain seperti reputasi tinggi, kompetensi dan akses (skor tinggi). Disini ada pertukaran antara biaya yang dikeluarkan dengan nilai yang didapat oleh pelanggan. Secara keseluruhan, kesenjangan yang terbentuk antara SILkargo dengan kompetitornya juga sebenarnya tidak terlalu jauh (hanya 0,32). Jadi sebenarnya yang terpenting bukanlah semakin menonjolkan prinsip pertukaran itu, tetapi SILkargo sebaiknya perlu melakukan suatu diferensiasi dengan biaya rendah secara bersamaan.

\subsection{Lingkungan Eksternal SILkargo}

SILkargo berada dalam industri logistik yang fungsinya sebagai logistics service provider (LSP). LSP ini merupakan pengelola pergerakan kargo pelanggan mulai dari titik asal barang hingga titik akhir tujuan, yang meliputi berbagai jenis moda transportasi. Jika melihat pada peta strategis maka dapat dilihat jika SILkargo berada dalam kelompok tiga sebagai mainly partial service with minor integrated service dengan kepemilikan asset - based. 
Jika dilihat berdasarkan bisnis area maka SILkargo cukup luas cakupannya. Dengan didukung oleh layanan dan jaringan yang kuat maka SILkargo dapat bermain di area domestik maupun international. Dengan para pemain di area domestik disini yang cukup kuat adalah : Kamadjaja Logistik, Pandawa Lima, Jasum, Puninar Logistik, MIF (sister company Meratus), dan TPIL (sister company SPIL).

Tetapi dengan posisi strategis yang melayani servis pada transportasi dan distribusi internasional serta domestik dapat membuat perusahaan logistik seperti ini terkadang tidak fokus terhadap target pasarnya. Sasaran pelanggan menjadi terlalu luas, mengingat banyaknya macam pergerakan kargo yang masuk ke dalam jenis sasaran layanan industri ini. Segmentasi pelanggan di industri logistik berdasarkan Rencana Strategis perusahaan SILkargo pada tahun 2007 - 2011, yaitu :

1. SEGMEN I : Kelompok Perusahaan atau Industri yang memiliki kompleksitas aktivitas logistik yang tinggi dengan tingkat penggunaan perusahaan jasa logistik yang minim/minor

2. SEGMEN II : Kelompok Perusahaan atau Industri yang memiliki tingkat kompleksitas aktivitas logistik menengah dengan tingkat penggunaan perusahaan jasa logistik yang tinggi

3. SEGMEN III : Kelompok Perusahaan atau Industri yang memiliki kompleksitas aktivitas logistik yang rendah (sederhana) dengan penggunaan perusahaan jasa logistik yang rendah

Jika melihat pada orientasi industri ini, maka terlihat bahwa industri logistik ini berkompetisi dominan terutama pada harga dan berfungsi berdasarkan kalkulasi utilitas atau manfaat. Dengan begitu orientasinya bersifat fungsional (rasional). Hal ini menjadikan arena persaingan industri logistik menjadi cenderung seragam. Hampir semuanya berfokus pada orientasi industri yang sama yaitu hal yang lebih bersifat fungsional. Dengan begitu dalam industri ini juga sebaiknya perlu mencermati hal lainnya yang lebih bersifat emosional, yang dapat memberikan nilai berbeda bagi pelanggannya.

Sedangkan untuk menggambarkan lingkungan eksternal, maka digunakan data BDI tahun 2009 seperti yang terlihat pada Gambar 3. Terlihat pada gambar tersebut bahwa terdapat beberapa faktor dari lingkungan eksternal makro yang mempengaruhi kondisi industri logistik. Faktor tersebut antara lain adalah trend industri berdasarkan pertumbuhan GDP tahun 2008 - 2009 dan makro ekonomi Indonesia dilihat dari pertumbuhan eksport sepanjang tahun 2007 - 2009 yang kesemuanya cenderung turun. Selain itu ada juga faktor pertumbuhan market untuk bidang logistik (3rd party) dan pertumbuhan investasi energi maupun non energi (domestik khususnya) tahun 2008 - 2009 yang cenderung meningkat. 

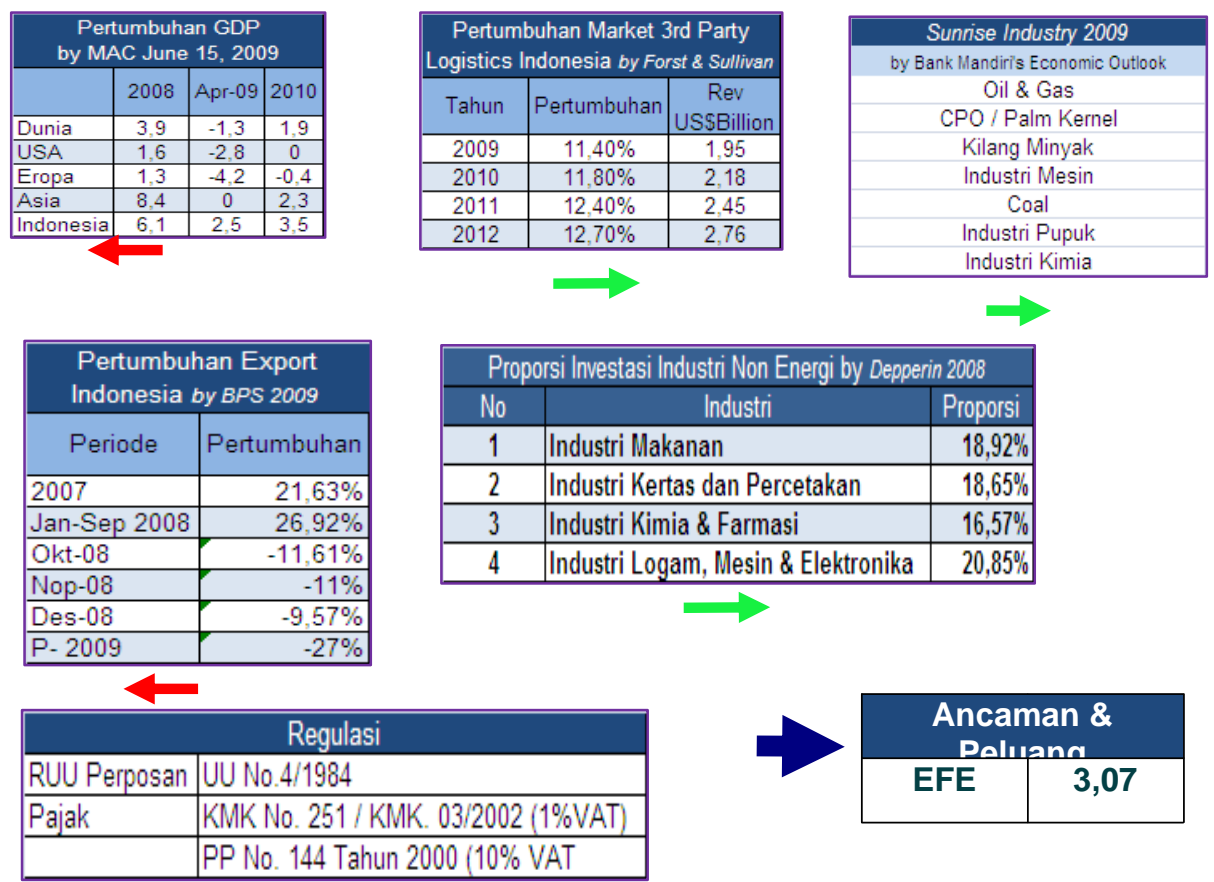

\begin{tabular}{|c|l|r|}
\hline \multicolumn{3}{|c|}{ Proporsi Investasi Industri Non Energi by Depperin 2008} \\
\hline No & \multicolumn{1}{|c|}{ Industri } & Proporsi \\
\hline 1 & Industri Makanan & $18,92 \%$ \\
\hline 2 & Industri Kertas dan Percetakan & $18,65 \%$ \\
\hline 3 & Industri Kimia \& Farmasi & $16,57 \%$ \\
\hline 4 & Industri Logam, Mesin \& Elektronika & $20,85 \%$ \\
\hline
\end{tabular}

Gambar 3.

Lingkungan Eksternal SILkargo

Ada kondisi global yang juga ikut mempengaruhi industri logistik yaitu era perdagangan bebas AGFTA (Asean - China Free Trade Agreement) yang mulai diberlakukan sejak 1 Januari 2010. Dengan semakin dibukanya jalur perdagangan bebas ini tentu akan mendorong peningkatan arus perdagangan internasional (ekspor - impor) maupun domestik. Untuk faktor regulasi justru dirasakan kurang menguntungkan bagi industri logistik ini. Adanya UU No.4 tahun 1984 menjadikan jasa pos dan kurir juga dapat melakukan layanan logistik. Selain itu mengenai aspek perpajakan, adanya KMK No 251 dan KMK 03 tahun 2002 menjadikan Jasa Titipan (courier service) hanya dikenakan PPN 1\% sedangkan PP No. 144 tahun 2000 menjadikan Jasa Pengurusan Transportasi (JPT) seperti SILkargo ini dikenakan PPN 10\% dari setiap kegiatannya. Regulasi ini menguntungkan industri kurir menjadi lebih fleksibel dan dapat mengakibatkan trend bisnis mereka semakin berkembang.

Dalam hal teknologi, menurut sumber ALI dalam materinya Arah Pengembangan Teknologi Logistik (2010), mengemukakan semakin berkembang penerapannya bagi industri penyedia jasa logistik. Hal ini dapat meningkatkan kapasitas sistem (efisiensi waktu operasi dan tonase), menurunkan resiko kerusakan dan kehilangan barang, memudahkan perencanaan, meningkatkan interoperability, dan meningkatkan keamanan. Solusi logistik terintegrasi juga nantinya diharapkan dapat dipenuhi dengan teknologi informasi dan komunikasi ini secara luas.

\subsection{Enam Kerangka Kerja BOS 5.3.1 Identifikasi Industri Alternatif} Seperti yang telah dikemukakan di atas bahwa SILkargo itu sendiri berada dalam industri Logistik, yang memiliki peran 
sebagai logistics service provider (yang selanjutnya akan disebut LSP). Berdasarkan presentasi manajemen mengenai Implementation SIG Logistic Business (2008), dalam Asosiasi Logistik Indonesia membagi jenis LSP menjadi tiga bagian besar yaitu Shippers, Express Couriers, dan Logistic Companies (Gambar 4.). Dengan begitu yang dijadikan alternatif dari industri Logistik ini adalah Shippers dan Couriers. Walaupun tujuan yang dimiliki sama yaitu mengelola pergerakan kargo mulai dari titik asal barang hingga titik akhir tujuan, tetapi memiliki bentuk yang berbeda.

\begin{tabular}{|l|l|l|l|l|l|}
\hline $\begin{array}{c}\text { Logistics } \\
\text { Service } \\
\text { Provider (LSP) }\end{array}$ & $\begin{array}{c}\text { Inbound } \\
\text { Logistics }\end{array}$ & $\begin{array}{c}\text { Manufactur } \\
\text { Materials Mgt }\end{array}$ & $\begin{array}{c}\text { Finished Goods } \\
\text { W/h-ing }\end{array}$ & $\begin{array}{c}\text { Customer } \\
\text { Delivery }\end{array}$ & $\begin{array}{c}\text { After Sales } \\
\text { Service }\end{array}$ \\
\hline Shippers & & & & & \\
\hline $\begin{array}{l}\text { Express } \\
\text { Couriers }\end{array}$ & & & & & \\
\hline $\begin{array}{l}\text { Logistics } \\
\text { Companies }\end{array}$ & & & & & \\
\hline
\end{tabular}

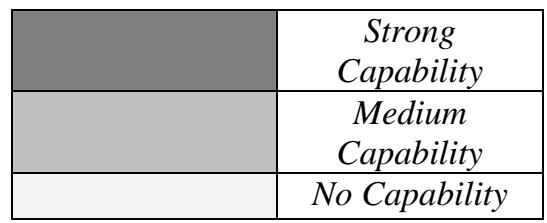

Gambar 4.

Logistics Service Provider Capabilities in Indonesia

SILkargo pernah melakukan survey (Tabel 2.) mengenai alasan mengapa perusahaan tertentu selama ini belum atau tidak ingin menggunakan jasa logistik. Dari hasil survey tersebut dapat dikemukakan bahwa mereka lebih memilih mengurus sendiri (shippers) misalnya, karena merasa dapat menanganinya sendiri $(28,95 \%)$ dan juga meragukan kemampuan perusahaan logistik dalam memenuhi standar yang diharapkan oleh mereka (23,68\%). Faktor lainnya seperti biaya yang dapat ditekan (39,47\%), dapat melakukan kontrol penuh terhadap pengawasan barang yang dikirim atau full-control (15,79\%), hingga alasan karena adanya kelengkapan sistem yang sudah dimiliki (10,53\%) dapat membuat pelanggan belum mau menggunakan jasa perusahaan logistik. 
Tabel 2.

Alasan Belum atau Tidak Ingin Menggunakan Jasa Logistik

\begin{tabular}{|l|c|}
\hline \multicolumn{1}{|c|}{ Alasan } & \% \\
\hline Biaya & 39,47 \\
\hline Dapat ditangani sendiri & 28,95 \\
\hline Ragu kemampuan total logistik & 23,68 \\
\hline Strategi perusahaan & 18,42 \\
\hline Full control & 15,79 \\
\hline Handling barang khusus & 15,79 \\
\hline Volume kecil & 10,53 \\
\hline Sudah punya sistem sendiri & 10,53 \\
\hline Tidak jelas info tentang logistik & 7,89 \\
\hline Kecepatan decision making & 5,26 \\
\hline Rahasia operasi & 2,63 \\
\hline Pemilihan dilakukan oleh pembeli (buyer) & 2,63 \\
\hline Kontinuitas tidak pasti & 2,63 \\
\hline Tidak ada yang menawarkan & 2,63 \\
\hline
\end{tabular}

Sedangkan pelanggan lebih memilih jasa kurir dikarenakan jasa ini dinilai memiliki kemampuan yang lebih dalam menangani barang khusus, baik dalam spesifikasi kemasan maupun barangnya itu sendiri (15,79\%). Selain itu apabila barang yang dikirimkan dalam volume kecil maka jasa kurir dalam bentuk paket juga dirasa lebih tepat (10,53\%).

\subsubsection{Identifikasi Alternatif Kelompok Strategis}

Pada tahap ini akan dicermati kelompok strategis lain dalam industri logistik. Seperti yang telah dikemukakan di atas bahwa SILkargo itu sendiri berada dalam kelompok 3 sebagai Mainly partial service with minor integrated service dengan kepemilikan asset - based.

Kelompok strategis lain dalam industri logistik yang pertama adalah perusahaan logistik yang partial services (basic). Lalu satu kelompok strategis lainnya adalah perusahaan logistik yang merupakan lead logistics provider. Berdasarkan materi Logistics Distribution pada seminar Strategic Sales Vision - Silkargo Indonesia (9 - 10 Juni 2008), dikemukakan bahwa ALI mengemukakan keunggulan service dan atribut yang ditawarkan oleh dua kelompok strategis tersebut adalah sebagai berikut :

1. Partial Services

Memiliki sifat Relationship \& Pricing Models sebagai berikut : focused cost reduction, handled specific services. Adapun Key Attributes yang mereka tawarkan adalah sebagai berikut : commodity, transaction

2. Total Logistics : Lead Logistics Provider Memiliki sifat Relationship \& Pricing Models sebagai berikut : project management, contract management, single point of contract, 3PL technology integration, strategic relationship. Adapun Key Attributes yang mereka tawarkan adalah sebagai berikut : contractual, risk sharing. 


\subsubsection{Identifikasi Alternatif Kelompok Pembeli}

Pada tahap ini akan dicermati rantai pembeli (purchaser, user, atau influencer) jasa SILkargo sebagai perusahaan logistik. SILkargo berfokus pada purchaser dan user sebagai rantai pembelinya. Keduanya dalam kaitannya dengan jasa SILkargo memiliki peran yang tidak jauh berbeda. Purchaser disini diposisikan sebagai bagian distribusi (purchasing) perusahaan, sedangkan user diposisikan sebagai perusahaan itu sendiri yang menginginkan agar barang sumber atau hasil produksinya dikirim ke titik tujuan tertentu.

Selain pihak purchaser dan user yang telah dijelaskan diatas, terdapat satu pihak lagi dalam rantai pembeli ini yaitu pihak influencer dalam pengambil-keputusan penggunaan jasa logistik. Disini dicermati bahwa yang berperan sebagai pemberi pengaruh adalah : pihak distibutor di tujuanatau penerima barang.

Dalam contoh pelanggan SILkargo (kasus PT. Philips) menunjukkan bahwa mereka akan memperhatikan referensi yang dianggap baik oleh para distributornya. Perusahaan penyedia jasa logistik yang akan menangani barang mereka sebaiknya memiliki cabang tetap di banyak tujuan di Indonesia. Pelanggan mengharapkan agar perusahaan logistik tersebut memiliki kantor cabang yang terpercaya di setiap titik tujuan distribusi komoditinya. Peran distributor disini jelas cukup berpengaruh dalam pengambil keputusan akan menggunakan perusahaan logistik yang mana. Dengan begitu faktor yang harus diperhatikan dalam mencermati rantai pembeli khususnya pemberi pengaruh ini adalah pentingnya jaringan dan juga kompetensi SDM yang dimiliki oleh kantor cabang.

\subsubsection{Identifikasi Alternatif Produk dan Jasa}

Pada tahap ini akan dicermati penawaran produk dan jasa pelengkap SILkargo sebagai pemain dalam industri logistik ini. Seperti yang telah dikemukakan di atas, bahwa produk dan jasa perusahaan logistik yang Mainly partial service with minor integrated service dapat digolongkan menjadi dua jenis, yaitu : jasa utama (Contract based door to door integrated logistics service) dan jasa tambahan (jasa freight forwarder).

Disini dicermati bahwa asuransi dapat menjadi produk dan jasa pelengkap dalam industri logistik ini. Masih berdasarkan Laporan Analisa Prospek Bisnis Logistik Domestik - PT. Phillips Indonesia menunjukkan bahwa adanya asuransi sangat penting dalam proses kegiatan yang dilakukan oleh penyedia jasa logistik. Selain asuransi, ada satu hal lagi yang menjadi pelengkap jasa logistik terkait dengan faktor keamanan barang yaitu adanya sistem tracking atau positioning system. Sistem ini bertujuan untuk memantau dan melacak keberadaan barang dan sudah banyak digunakan untuk pengiriman paket barang atau container untuk yang ocean going. Sedangkan untuk shipment inter-insular (domestik) hal ini belum diterapkan oleh perusahaan logistik.

Modifikasi dari sistem tracking atau positioning system dapat berupa Bar Coding, yang sudah banyak dilakukan diperusahaan kurir. Hal ini merupakan kombinasi dari teknologi informasi dan komunikasi di bisnis logistik, yang memungkinkan container maupun barangnya langsung dapat dipantau keberadaannya dalam sistem distribusi. Hal ini juga dapat mengatasi hambatan respon dan tanggapan antara karyawan dengan pelanggan shipment domestik yang sangat rentan akan keterlambatan armada (schedule 
delay, long sailing time, shoot-out container, traffic jam).

\subsubsection{Identifikasi Alternatif Orientasi Daya Tarik Industri}

Pada tahap ini akan dicermati orientasi daya tarik fungsional dan emosional industri. Seperti yang telah dikemukakan di atas, bahwa daya tarik industri logistik ini lebih bersifat fungsional (rasional). Dengan begitu pada tahap kelima ini harus diperhatikan juga orientasi daya tarik lainnya, yaitu yang bersifat emosional. Jika mencermati kembali pada Tabel 2., maka dapat dikemukakan bahwa alasan yang menyebabkan pelanggan memilih jasa lain karena adanya ketidakpercayaan terhadap perusahaan logistik. Seperti pelanggan yang mengemukakan bahwa mereka ragu terhadap kemampuan total logistik (23,68\%) itu menunjukkan bahwa faktor kepercayaan menjadi penting agar perusahaan logistik dapat dipilih oleh pelanggannya. Hal inilah yang dikatakan daya tarik industri yang bersifat emosional.

Selain itu juga ada pelanggan yang mengemukakan bahwa mereka merasa adanya rahasia operasi yang dimiliki perusahaan $(2,63 \%)$ dan kontinuitas yang tidak pasti $(2,63 \%)$ menunjukkan pentingnya faktor kepercayaan tersebut. Pelanggan dapat saja merasa khawatir bahwa perusahaan logistik yang akan mereka gunakan nantinya dapat mengetahui detail kegiatan operasi mereka yang merupakan bagian 'dapur' perusahaan. Ditambah lagi mereka merasa bahwa kontinuitas dengan perusahaan logistik yang tidak bertahan lama (bisa berganti - ganti) semakin menjadikan faktor kepercayaan menjadi salah satu pertimbangan mereka.

Dengan begitu perusahaan logistik harus mulai memperhatikan orientasi yang bersifat emosional. Perusahaan harus mampu meyakinkan pelanggannya dalam mengatasi kekhawatiran yang disebutkan diatas. Adanya kepercayaan dan kenyamanan yang dapat ditumbuhkan dalam benak pelanggan inilah menjadi penentu keberhasilan perusahaan dalam menarik pangsa pasar baru.

\subsubsection{Identifikasi Trend Industri}

Pada tahap ini akan dilakukan identifikasi waktu. Telah dikemukakan di atas, bahwa ada kecenderungan peningkatan investasi energi dan non-energi di area domestik, terbukanya AGFTA yang mendorong perkembangan bisnis logistik, kondisi bisnis kurir yang semakin lincah dan agresif, serta teknologi informasi dan komunikasi maka akan membentuk suatu trend baru pada industri logistik ini.

Trend yang dapat mempengaruhi industri logistik adalah penggunaan sistem yang bersifat otomatisasi dalam menangani shipment domestik. Otomatisasi ini disebut e-commerce atau electronic commerce. Mulai dari proses pemesanan hingga pembayaran oleh pelanggan menjadi lebih efisien dan sistematis. Selain itu trend yang dapat terjadi adalah semakin pentingnya peran kemitraan. Dengan semakin meningkatnya potensi bisnis domestik (energi dan non-energi) maka menciptakan pengiriman barang antar pulau yang semakin besar. Dengan keterbatasan armada dan fasilitas yang dimiliki perusahaan logistik, maka harus terjalin kerjasama yang kuat dengan para vendor terkait. Vendor disini termasuk didalamnya vendor transportasi laut, transportasi darat, vendor jasa asuransi, vendor depo container, dan lainnya.

\subsection{Langkah Kegiatan BOS \\ 5.4.1 Perumusan Kanvas Strategi}

Sumbu horisontal kanvas ini merangkum faktor apa saja yang dijadikan ajang kompetisi industri logistik. Berdasarkan materi pembentukan sub- 
holding logistik SIG (2009 - 2010) maka faktor kunci industri logistik selama ini adalah : harga, network, dukungan IT dan sistem informasi, kepemilikan asset (gudang, alat transportasi / armada), kompetensi SDM, dan reputasi global. Sedangkan sumbu vertikal merangkum tingkat penawaran yang didapatkan pembeli di semua faktor kompetisi. Seperti yang telah dikemukakan pada Tabel 1 mengenai perbandingan key attribute logistic, maka didapatkan skor antara SILkargo dengan kompetitornya. Perbandingan skor (Tabel 3.) ini yang akan digunakan sebagai sumbu vertikal.

Tabel 3.

Perbandingan Faktor Kompetisi SILkargo dengan Kompetitor

\begin{tabular}{|c|l|c|c|}
\hline No & Faktor Kompetisi & Skor SILkargo & Skor Kompetitor \\
\hline 1 & Harga & 2,83 & 2,95 \\
\hline 2 & Network & 3,17 & 2,94 \\
\hline 3 & $\begin{array}{l}\text { Dukungan IT dan } \\
\text { Sistem Informasi }\end{array}$ & 3,12 & 2,95 \\
\hline 4 & Kepemilikan Aset & 3,13 & 2,78 \\
\hline 5 & Kompetensi SDM & 3,30 & 2,83 \\
\hline 6 & Reputasi Global & 3,38 & 2,73 \\
\hline
\end{tabular}

Dengan begitu dapat dibuat kanvas strategi (Gambar 5.) yang menggambarkan kondisi SILkargo dan perusahaan logistik lainnya (kompetitor) pada saat ini. Hal ini menghasilkan suatu bentuk kurva yang disebut kurva nilai. Kurva inilah yang merupakan komponen dasar dari kanvas strategi sebagai penggambaran grafis mengenai kinerja relatif perusahaan berkenaan dengan faktor kompetisi dalam industri.

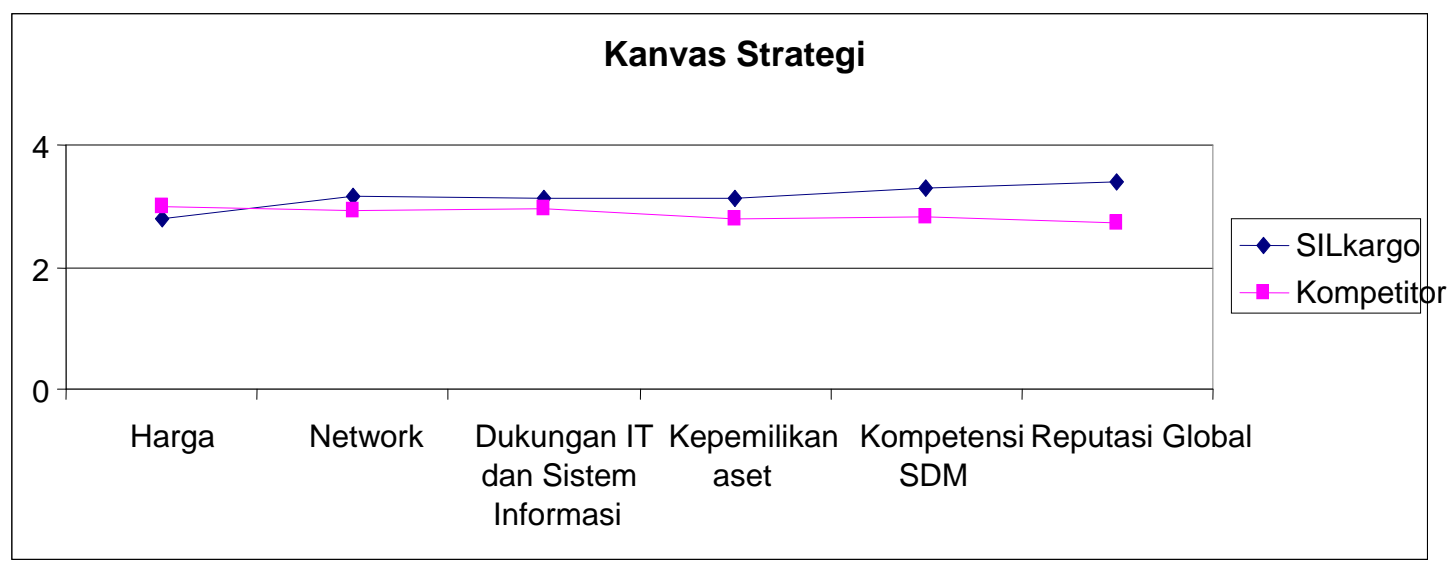

Gambar 5.

Kanvas Strategi Industri Logistik (Konvensional) 
Pada gambar tersebut dapat dikatakan bahwa kedua kurva nilai dari SILkargo dan para kompetitornya memiliki bentuk dasar yang sama. Hal ini menunjukkan strategi yang mereka jalani sekarang ini cenderung seragam, tetapi dengan tingkat pemberian penawaran yang berbeda. Disini jelas ada pertukaran antara biaya yang dikeluarkan dengan nilai yang didapat oleh pelanggan (prinsip dilemma trade off). SILkargo dengan tarifnya yang lebih tinggi menawarkan keunggulan pada faktor lainnya, sedangkan sebaliknya yang terjadi pada perusahaan lain yaitu menerapkan tarif yang lebih rendah tetapi memiliki faktor kunci yang berada dibawah SILkargo.

\subsubsection{Perumusan Kerangka Kerja Empat Langkah dan Skema ERRC}

Kerangka kerja empat langkah ini terdiri dari empat hal pokok yaitu sebagai berikut : (1) Faktor yang harus dihapuskan : kepemilikan aset, (2) Faktor yang harus dikurangi : harga dan reputasi global, (3) Faktor yang harus ditingkatkan : network, dukungan IT dan sistem informasi, serta kompetensi SDM, (4) Faktor yang harus diciptakan : keamanan dan vendor management. Dari keempat kerangka kerja yang telah dibuat tersebut maka dapat digambarkan dalam bentuk kanvas strategi dengan kurva nilai yang baru (Gambar 6.) dan bersifat BOS didalamnya.

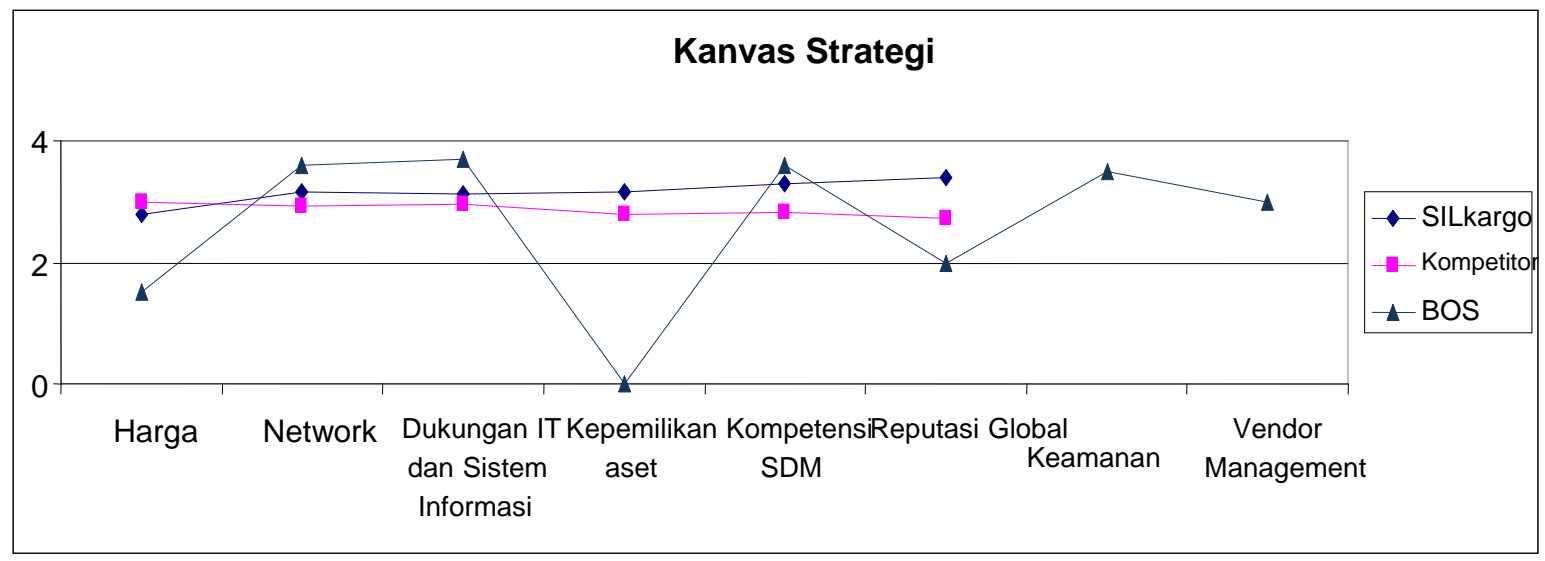

Gambar 6.

Kanvas Strategi Industri Logistik (BOS)

Dari gambar tersebut terlihat kurva baru memiliki bentuk dasar yang sangat berbeda dengan kedua kurva sebelumnya. Hal ini menunjukkan bahwa strategi yang akan dijalani kurva baru tersebut juga akan berbeda. Kurva nilai inilah mulai mendobrak logika lama yaitu keharusan untuk memilih antara nilai tinggi atau kepemimpinan biaya. Dari sini dapat dibuat sebuah skema ERRC (Tabel 4.) yang merupakan pelengkap bagi kerangka kerja empat langkah ini. 
Tabel 4.

ERRC Grid SILkargo

\begin{tabular}{|l|l|}
\hline $\begin{array}{l}\text { Menghapuskan } \\
\text { Kepemilikan Aset }\end{array}$ & $\begin{array}{l}\text { Meningkatkan } \\
\text { Network } \\
\text { Dukungan IT dan Sistem Informasi } \\
\text { Kompetensi SDM }\end{array}$ \\
\hline Mengurangi & $\begin{array}{l}\text { Menciptakan } \\
\text { Keamanan } \\
\text { Reputasi Global }\end{array}$ \\
\hline
\end{tabular}

\subsubsection{Perumusan Rangkaian Strategi}

Identifikasi rangkaian tersebut secara nyata dapat dijelaskan sebagai berikut :

1. Menghapuskan dan mengurangi

SILkargo sebaiknya jangan

memfokuskan pada pembelian dan penambahan aset seperti armada transportasi, gudang, ataupun depo container terlebih dahulu. Biaya yang dibutuhkan untuk investasi barang tersebut sangat besar dan cukup beresiko. Sama halnya pada armada angkutan darat (truk), SILkargo cabang Jakarta sendiri hanya memiliki dua truk box model CDE (colt diesel engkel) dan CDD (colt diesel double). Tetapi pembelian jenis armada ini membutuhkan investasi yang cukup besar. Dengan menghilangkan penambahan atau pembelian aset nantinya akan terkait dengan dilakukannya vendor management yang kuat. Jadi dengan begitu SILkargo sebaiknya menjadi tidak terlalu fokus pada kegiatan penambahan aset ini yang terlalu besar, dan sisi lain hal ini dapat diatasi dengan alternatif adanya vendor management.

2. Meningkatkan dan menciptakan

Hal yang penting untuk ditingkatkan kualitasnya adalah IT - sistem informasi, network dan kompetensi SDM. Dengan network yang luas tentu dapat memberi nilai tambah ketika memilih perusahaan logistik. Terutama dalam lingkup domestic shipment, dimana negara Indonesia ini merupakan negara kepulauan yang luas dan beragam, maka semakin banyak cabang yang dimiliki dapat meningkatkan jasa logistik terintegrasi. Dengan begitu pengembangan SDM jangan hanya ditekankan pada kantor pusat, melainkan pada kantor cabang juga harus diperhatikan.

Begitu juga dengan IT dan sistem informasi, seperti yang telah dijelaskan pada Bagian lima bahwa faktor ini akan berkembang dan trend kedepannya menjadi penting. Pengembangan sistem bersifat $e$ commerce dapat digunakan, dimana pengelolaan menjadi aliran dokumen tanpa kertas. Dengan begitu dapat menambah kecepatan pengiriman order dan proses pembayaran, mereduksi periode pembayaran, meningkatkan kinerja bagian operasi, serta dapat mengirimkan informasi sekaligus ke beberapa partisipan secara akurat. Tidak akan muncul lagi proses birokrasi internal yang rumit (tandatangan kepala bagian, alih surat perintah kerja antar bagian, menunggu fax shipping instruction).

Pada faktor keamanan dapat dibuat suatu control system, misalnya mempermudah akses tracking and tracing, mengecek jangkauan service, dan penyediaan jasa tambahan. Hal ini juga berkaitan dengan faktor keamanan dengan adanya penerapan sistem Bar Coding, asuransi barang dan tanggung jawab (lialibilities).

Dalam hal menciptakan vendor management, SILkargo dapat memanfaatkan armada yang ada pada bisnis unit Samudera Indonesia Group. Faktor harga yang merupakan pertimbangan penting justru 
dapat dikelola dengan baik melalui vendor management ini. Dengan semakin meningkatnya kerjasama yang baik dengan vendor maka tarif yang diberikan juga dapat lebih ditekan. Jika selama ini shipment domestik yang banyak melibatkan vendor lokal kurang efisien, maka dengan adanya vendor management yang kuat ini akan meningkatkan kinerja operasional, mempercepat proses pengambilan keputusan dan kesanggupan melayani berbagai macam permintaan pelanggan (handling special shipment). Perlu diketahui bahwa shipment domestik sangat berbeda kondisinya dengan internasional. Ada beberapa perusahaan logistik yang dapat menjadi 'mafia' bagi vendor tertentu sehingga sangat mendominasi. Kondisi yang selama ini menjadikan perusahaan logistik 'bergantung' pada vendornya, akan menjadi suatu bentuk kerjasama yang posisinya sama kuat dan menguntungkan kedua belah pihak. Hal ini tentunya juga dapat mendukung pentingnya pengadopsian dari pihak stakeholder perusahaan sebagai bagian dari identifikasi rangkaian BOS.

Berdasarkan uraian inilah maka dapat diusulkan adanya pengembangan sistem internal bersifat electronic commerce, control system dan vendor management. Dengan identifikasi rangkaian, maka kegiatan tersebut dapat diusulkan sebagai rancangan BOS. Perlu diketahui bahwa sesuai dengan konsep BOS bahwa inti dari rancangan ini adalah adanya suatu rangkaian kegiatan yang bersifat inovatif dan dapat menjadikan bisnis unggul serta berkelanjutan.

\section{KESIMPULAN DAN SARAN}

Proses identifikasi enam kerangka kerja BOS memperlihatkan beberapa hal yang dianggap penting dan mempengaruhi industri logistik, yaitu : minimalisasi biaya, kontrol dan pengawasan penuh terhadap barang, keamanan dan kenyaman yang dirasakan, kemampuan yang lebih dalam menangani barang yang khusus, network dan juga kompetensi SDM yang dimiliki. Ketika membuat kerangka kerja empat langkah dan skema ERRC diketahui bahwa faktor yang harus dihapuskan adalah kepemilikan aset, faktor yang harus dikurangi adalah harga dan reputasi global, faktor yang harus ditingkatkan adalah network, dukungan IT dan sistem informasi, kompetensi SDM, sedangkan faktor yang harus diciptakan adalah keamanan dan vendor management. Dari keseluruhan hasil identifikasi tersebut dapat dibuat kanvas strategi BOS yang memiliki bentuk dasar berbeda. Dapat dirangkum bahwa kegiatan baru yang diusulkan adalah penerapan sistem yang dapat bersifat electronic commerce (otomatisasi), adanya control system dan vendor management. Setelah melakukan identifikasi rangkaian strategis, maka kegiatan tersebut dapat diusulkan sebagai rancangan BOS dalam rangka menjadikan bisnis lebih unggul dan berkelanjutan.

Terkait dengan usulan kegiatan, dapat dibuat suatu prioritas dan kriteria dasar dalam rangka vendor management. Selain itu, rancangan strategis yang menggunakan landasan konsep BOS harus sangat mengutamakan inovasi nilai dengan analisis dan argumentasi jelas serta logis. Oleh karena itu jenis penelitian BOS selanjutnya dapat disertai metode survey yang mendalam, pengamatan, dan kerjasama dalam sebuah tim yang kuat. Dengan begitu usulan program atau kegiatan yang dihasilkan memiliki tingkat inovasi nilai tinggi dan signifikan bagi objek penelitiannya. 


\section{DAFTAR PUSTAKA}

Asosiasi Logistik Indonesia (ALI). Arah Pengembangan Teknologi Logistik. Materi Seminar. Jakarta, 2010. Antariksa, Yodhia. (2009).Tiga Cerita Blue Ocean Strategy. http://www.bfionline.web.id/blc/index.

B.S., Mohammad. A. (2009). Industri Logistik : Segudang Peluang di Tengah Aneka Tantangan. http://swamajalah/swaplus/details.

David, Fred. R., Strategic Management : Concepts and Cases. 12th Edition. New Jersey : Pearson Prentice Education International, 2009.

Govindarajan, Vijay \& Trimble, Chris. 10 Rules for Strategic Innovators - From Idea to Execution. Boston : Harvard Business School Publishing, 2005.

Umar, Husein. Strategic Management In Action : Konsep, Teori, dan Teknik Menganalisis Manajemen Strategis - Strategic Business Unit. Jakarta : PT. Gramedia Pustaka Utama, 2001.

Kim, W. Chan \& Mauborgne, Renee. Blue Ocean Strategy. Strategi Samudera Biru (Terjemahan). Cetakan kesepuluh. Jakarta : Serambi Ilmu Semesta, 2009. (Original publisher : Harvard Business School Publishing Corporation. 2005).

PPM. Pedoman Pelaksanaan dan Penulisan Tesis. 2009.

PT. SILkargo Indonesia. Manual Bisnis Proses 2007. SILkargo, 2007.

Syrett, Michael. Successful Strategy Execution : How to keep your business goals on target. London : Profile Books Ltd, 2007.

Tim Samudera Indonesia Group. Carriage of Goods by Sea. Materi SIMDP XXII Samudera Indonesia Group. Jakarta : SIG, 2007.

Tim SILkargo Indonesia. Business Plan 2009 - 2013. Jakarta : SILkargo, 2009.

-----. Corporate Strategic Plan 2007 - 2011. Jakarta : SILkargo, 2007.

------. Implementation SIG Logistic Business. Jakarta : SILkargo, 2008

------. Logistics Distribution. Materi seminar Strategic Sales Vision - SILkargo Indonesia. Jakarta : SILkargo, 9 - 10 Juni 2008.

Utaminingsih, Ina Astari. Laporan On The Job Training - Pengembangan Bisnis Jasa Movers PT. SILkargo Indonesia. Samudera Indonesia Management Development Program. SIMDP XXII, 2008.

www.blueoceanstrategy.com. Index. 2009.

www.samudera.com. Strategic Theme. 2010.

www.silkargo-ina.co.id. Strategic Theme. 2010 